\title{
Novo ano, novos desafios!
}

Um levantamento das estatísticas do JBCS para o ano que passou mostra que os nossos indicadores de progresso, em sua maioria, permaneceram estáveis: número de manuscritos submetidos (774), número de trabalhos publicados (300), percentual majoritário de submissões de autores do exterior (60\% do total) - ainda que os artigos publicados tenham tendência oposta (70\% de autores brasileiros) - e índices de citações, como o avaliado pelo fator de impacto do Institute of Scientific Information (ISI, acima de 1,3), entre outros. Já o tempo entre submissão e publicação on-line vem diminuindo lenta mas continuamente: em 2011, esse indicador atingiu um valor médio de 5,4 meses, versus 8,1, 7,7 e 6,6 meses em 2008, 2009 e 2010 respectivamente. Este desempenho é bom ou ruim?

Parte da resposta envolve avaliar o que esperamos para a nossa revista no futuro. Agora que o periódico entra no seu $23^{\circ}$ ano de existência, uma retrospectiva crítica evidencia que muitas etapas de desenvolvimento já foram consolidadas: primeiro a sobrevivência como uma revista de Química editada fora dos países da América do Norte ou Europa; depois a internacionalização, com a indexação nas mais importantes bases de dados internacionais, e o reconhecimento através de parâmetros como o fator de impacto calculado pelo ISI. No âmbito interno, a expansão do corpo editorial para incluir os (atuais) 12 editores associados, e do corpo gerencial e de processamento, que atualmente é integrado por sete membros, contribuiu de forma marcante para o aumento no ritmo de publicação e para a consolidação dos doze fascículos anuais agora publicados no JBCS. Nesse contexto, a boa nova mais recente é a inclusão da Profa. Vanessa Hatje, da Universidade Federal da Bahia (UFBA), no grupo de Editores Associados. A Profa. Hatje é uma especialista em Oceanografia Química e a sua entrada no corpo editorial é um reflexo da importância desta área de estudos ainda emergente no país. Bem-vinda, Vanessa!

$\mathrm{Na}$ continuidade desse processo de crescimento, avaliamos que ainda há espaço para diversos novos desafios, os quais incluem a manutenção do equilíbrio financeiro necessário à publicação regular do Journal . Para isso, continuamos contando com o apoio decisivo da Sociedade Brasileira de Química (SBQ) e da Universidade de Campinas para a manutenção da infraestrutura física e de recursos humanos necessária ao funcionamento da revista. Ainda, ao ratificarmos nossa adesão ao modelo de open access, que disponibiliza e divulga mundialmente todo o conteúdo publicado no Journal, e contando apenas com contribuições financeiras voluntárias dos autores, temos conseguido manter o nosso balanço de pagamentos através da contribuição contínua das agências de fomento (FAPESP, CNPq e CAPES), que têm contemplado os projetos de suporte financeiro elaborados pela equipe do JBCS. Estes apoios permitiram, por exemplo, que mantivéssemos rigorosamente em dia a publicação dos doze números do JBCS em 2011.

Por outro lado, esta estrutura ainda é bastante limitada para garantir um funcionamento compatível com o oferecido por editoras comerciais, as quais regularmente convidam o JBCS para integrar as suas respectivas carteiras de periódicos de acesso pago. Manter a estrutura atual do Journal garantindo o acesso eletrônico gratuito, além de ampliá-la e avançar no seu processo de profissionalização, só serão possíveis com as novas iniciativas que vêm sendo discutidas por agências como a CAPES e a FAPESP. Vencer a barreira da profissionalização com o suporte indispensável dos órgãos de fomento - garantirá a continuidade do modelo de gestão das revistas por sociedades científicas versus a opção, de outra forma quase compulsória, pelas propostas que vêm sendo feitas por Editoras comerciais. 
A avaliação da necessidade ou mesmo sustentabilidade da publicação em papel, que tem um custo muito elevado, é outro ponto de uma discussão já recorrente entre Editores. Propomos que este tema seja tratado também pela SBQ e pela comunidade alvo e parceira dos periódicos editados pela Sociedade, com a maior brevidade possível.

Uma maior integração, visando ao trabalho em conjunto com outras revistas de Química publicadas pela SBQ e outras entidades, também deve ser buscada. A produção científica da comunidade nacional e internacional que procura ser veiculada em nossas revistas é ampla o suficiente para justificar a publicação de diversos periódicos, mas é importante que cada um procure definir o seu perfil para consolidar uma atuação conjunta e complementar, sem uma postura competitiva. O fato das grandes sociedades científicas mundo afora serem responsáveis pela editoração harmoniosa de diferentes revistas, com características distintas, constitui um modelo que certamente pode ser adotado e ajustado à realidade do nosso país.

Mas sempre é bom um pouco de novidade. Para este ano, concluiremos a revisão do site da revista, inclusive do sistema de submissão e processamento de manuscritos, visando a modernizar e facilitar o acesso pelos autores, revisores, editores e administradores. Os editores também atuarão, de forma pró-ativa, na organização de números especiais temáticos, uma iniciativa que vem sendo bem sucedida na atração de trabalhos qualificados e de maior impacto, e que tem contribuído para a ampliação do alcance da revista. Neste sentido, sugestões são muito bem-vindas.

É assim que o JBCS se planeja e se renova para este ano que começa. Nunca é demais lembrar que, no estágio em que a revista se encontra, estacionar é andar para trás. Por isto temos que nos manter em igual ou maior atividade em relação à registrada nos anos anteriores, que levou às diversas inovações implementadas recentemente no JBCS.

Agradecemos mais uma vez pelo contínuo apoio recebido de nossos colegas, principalmente dos revisores que, com seu trabalho voluntário e confidencial, garantem a manutenção dos padrões de qualidade da nossa revista. Desejamos a todos um 2012 cheio de realizações. 